\title{
Pietraforte, the Florentine building material from the Middle Ages to contemporary architecture
}

\author{
${ }^{1}$ Department of Earth Sciences- University of Firenze, Via G. La Pira, 4, Firenze, Italy \\ ${ }^{2}$ CNR- ISPC - Institute of Heritage Science (Florence Unit), Via Madonna del Piano, 10, Sesto Fiorentino, Firenze, Italy; *Corresponding \\ author,E-mail:fabio.fratini@cnr.it; emma.cantisani@cnr.it; silvia.vettori@cnr.it \\ ${ }^{3}$ CNR-IGG - Institute of Geosciences and Earth Resources (Florence Unit) - Via G. La Pira, 4, Firenze, Italy
}

(Received: April 20, 2020; Revised accepted: September 23, 2020)

https://doi.org/10.18814/epiiugs/2020/020087

Pietraforte sandstone is the building material of the Medieval Florence (Italy). This was due to the proximity of its quarries to the city, its availability, ease extraction from the quarry face and to the particular characteristics of durability of the stone, suitable for the buildings and monuments cladding. Florence can be defined as a city in Pietraforte, and this makes it necessary its detailed characterization. The paper reports the geological setting of the Pietraforte sandstone, the mineralogical-petrographic characterization, the physical parameters and also a mineralogical method (based on clay minerals association) for the identification of the source quarries of the most important historical buildings. The knowledge of this lithotype allowed to better understand its decay phenomena.

\section{Introduction}

The city of Florence, located in central Italy, is a UNESCO World Heritage Site since 1982. It is universally recognized as one of the most important cities of the world for its artistic and architectural heritage (Fig. 1). It is located in the SE corner of the Firenze-Prato-Pistoia basin, one of the tectonic basins that evolved during the NeogeneQuaternary extensional events occurring in the hinterland of the Late Oligocene-Miocene Northern Apennines thrust and fold belt. The substratum of the basin consists of Ligurian Units, belonging to the Jurassic-Eocene Ligurian-Piedmontese oceanic paleogeographic area, which are tectonically overlaid onto the Tuscan Units representing a part of the Adriatic paleocontinental margin (Bortolotti et al., 2001; Vai and Martini, 2001) (Fig. 2). For centuries, the sandstones of the turbidite formations belonging to these units (Ligurian Units and Tuscan Units) provided the building materials used primarily during the Middle Ages and Renaissance, determining the particular colour of the city: ochraceous shades for the aristocratic residential and public administration buildings and flagstones for street paving made from Pietraforte sandstone (Fig. 3a); cerulean colour for the large colonnades and ornamental architectonic elements of churches and import- ant houses realized with Pietra Serena sandstone (Fig. 3b). In particular, Pietraforte was the primary building material (from Middle Ages) of the city, while Pietra Serena was used extensively with the advent of Renaissance, when large blocks of this latter sandstone were required to carve columns, capitals and other ornamental elements (Rodolico, 1964; Fratini and Rescic, 2013; Fratini et al., 2015). The extensive utilization of Pietraforte was mainly due to: 1) the proximity of its quarries to the city (the hills near to the left bank of the River Arno e.g. Boboli) (Fig. 4); 2) the ease of its extraction from the quarry face favoured by the thickness of the arenaceous beds (separated by shaly intercalations) that varies from a few decimetres to $1.5 \mathrm{~m}$; 3 ) the presence of internal secondary discontinuities like fractures filled with calcite veins that allow an ease shaping of the material (Fig. 5); 4) its characteristics of durability.

The aim of this paper is to summarize the lithological-sedimentary, compositional and physical features of Pietraforte, particularly of the Florence area, define the source quarries for many important buildings of the $\mathrm{XIV}^{\text {th }}-\mathrm{XVI}^{\text {th }}$ centuries in the city, and also to describe the problems of its conservation.

\section{Historical use of Pietraforte in Florence}

The utilization of Pietraforte dates back to the Roman period, as documented by the archaeological excavations near Palazzo Vecchio, where some structures of the Roman theatre of Florentia were uncovered (Sartori, 2002), however, its extensive use dates to the XII ${ }^{\text {th }}$ century when the city began to expand and to increase in importance, with the construction of new city walls incorporating the $\mathrm{XI}^{\text {th }}$ century Matildine walls (built on the wall of the Roman castrum). A further expansion is related to the construction of the XIII ${ }^{\text {th }}$-XIV ${ }^{\text {th }}$ century walls (Sznura, 1975; Artusi, 2005), when Florence attained the importance of other great European cities. The typical buildings of that period were tower houses (to protect families from violence arising from private revenge and from the struggle between political-social factions) (Fig. 6a) or public buildings as the Palazzo del Bargello (Fig. 6b), that were constructed with mostly unworked stone blocks. After the middle of the $\mathrm{XIII}^{\text {th }}$ century and during the $\mathrm{XIV}^{\text {th }}$ century (when the municipality issued 


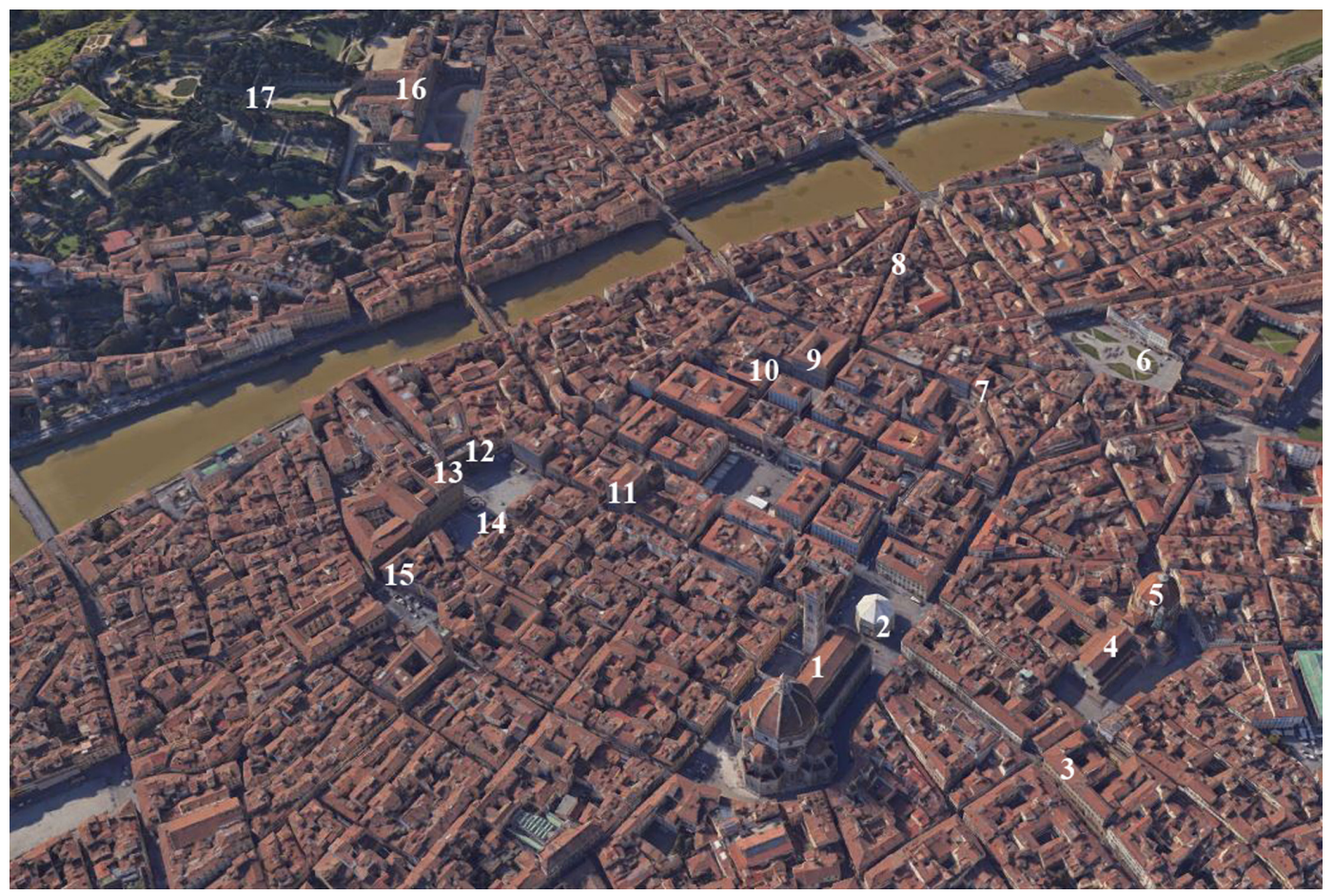

Figure 1. Aerial view of Florence: the most important churches and historic buildings are indicated. (1 = Cattedrale di Santa Maria del Fiore; 2 = Battistero di San Giovanni; 3 = Palazzo Medici Riccardi; 4 = Basilica di San Lorenzo; 5 = Cappelle Medicee; $6=$ Piazza Santa Maria Novella; 7 = Palazzo Antinori; 8 = Palazzo Rucellai; $9=$ Palazzo Strozzi; 10 = Strozzino; 11 = Chiesa di Orsanmichele; 12 =Loggia dei Lanzi; 13 = Palazzo Vecchio; 14 = Palazzo Uguccioni; 15 = Palazzo Gondi; 16 = Palazzo Pitti; 17 = Giardino di Boboli).

an order to crop all the towers to give a visible signal that the power of the noble families had finished), other public buildings began to be erected in Pietraforte, including Palazzo Vecchio, Loggia dei Lanzi, Cattedrale di Santa Maria del Fiore (completely clad with white Carrara marble, bands of green serpentinite and red limestone) as well as numerous palaces of the emerging artisanal middle class that made Florence one of the largest and richest cities in Europe. In addition, the Loggia housing the grain market (Orsanmichele) was built between 1337 and 1350, with refined three lancet windows, which is one of the few examples of sculptured Pietraforte. In the $\mathrm{XV}^{\text {th }}$ century, with the advent of the Renaissance, the families of the wealthy bourgeoisie had impressive palaces built using quarry-faced ashlars called bugnato (e.g., bugnato rustico of Palazzo Medici Riccardi by Michelozzo, Palazzo Pitti by Luca Fancelli, Palazzo Strozzi by Benedetto da Maiano (Fig. 7a); bugnato liscio (Fig. 7b) of Palazzo Antinori and Palazzo Rucellai by Leon Battista Alberti) (Malesani et al., 2003; Pecchioni et al., 2012). The utilization of Pietraforte continued also in the XVI ${ }^{\text {th }}$ century e.g. in Palazzo Uguccioni in Piazza Signoria. In the XVII ${ }^{\text {th }}$ century, the façades were covered less in stone and more in renders and graffito plasters. Nevertheless, Pietraforte was still utilized for the Chiesa di San Michele and San Gaetano and for San Filippo Neri convent, which are the few examples of "Florentine Baroque". With the advent of Art Nouveau in the late $\mathrm{XIX}^{\text {th }}$, early $\mathrm{XX}^{\text {th }}$ century, the use of natural stone materials was partly abandoned in favour of artificial stone, thanks to the development of modern binders (Portland cement). However, there are still many examples of the use of Pietraforte in this period, for example for the architectural parts of the Piazzale Michelangelo by Poggi and as for specific houses and villas of rich families imitating Medieval architec- ture (Neogothic or Romantic architecture as the Torre del Gallo close to Viale Galileo). In more recent times, Pietraforte was the stone that the architect Giovanni Michelucci used as cladding for Santa Maria Novella railway station (1934-1935), a masterpiece of rationalist architecture (Conforti et al., 2016). He preferred this material to travertine and marble, that were in fashion at that time. It is worth mentioning that outside Florence, Pietraforte is also the main building material of Montalcino, along the Francigena road south of Siena and Poppi in Casentino, with its imposing castle, both in Tuscany.

\section{Geological Setting}

Pietraforte sandstone was defined with this name by Brocchi (1814), Sacco (1895) and Lotti (1910), but its main features were pointed out by Losacco (1958). Pietraforte sandstone is a lithotype of the eponymous formation belonging to the allochthons External Ligurid Units (Calvana Supergroup or Calvana tectonic Unit) which thrust on the SubLigurian (Canetolo Unit) and Tuscan Nappes (Tuscan Nappe and Cervarola-Falterona Unit) (Abbate and Sagri, 1970; Bortolotti et al., 2001; Vai and Martini, 2001; Nirta et al., 2005). The formation is dated to the Upper Cretaceous (Bortolotti, 1962; Fontana, 1991) and it is intercalated as wide lenses with thicknesses variable from several tens of metres to about $450 \mathrm{~m}$ and locally 700-800 m (e.g., Greve, in the Chianti Mounts), in the mostly shaly basal complexes of the Calvana Unit succession (e.g., Sillano Formation, S. Fiora Formation) that underlies the marly limestone and marl turbiditic succession of the PaleoceneEocene Monte Morello Formation (Alberese Auctt.) (Bortolotti, 1962, 1963; Abbate and Sagri, 1970; Falorni, 2001). The depositional area 


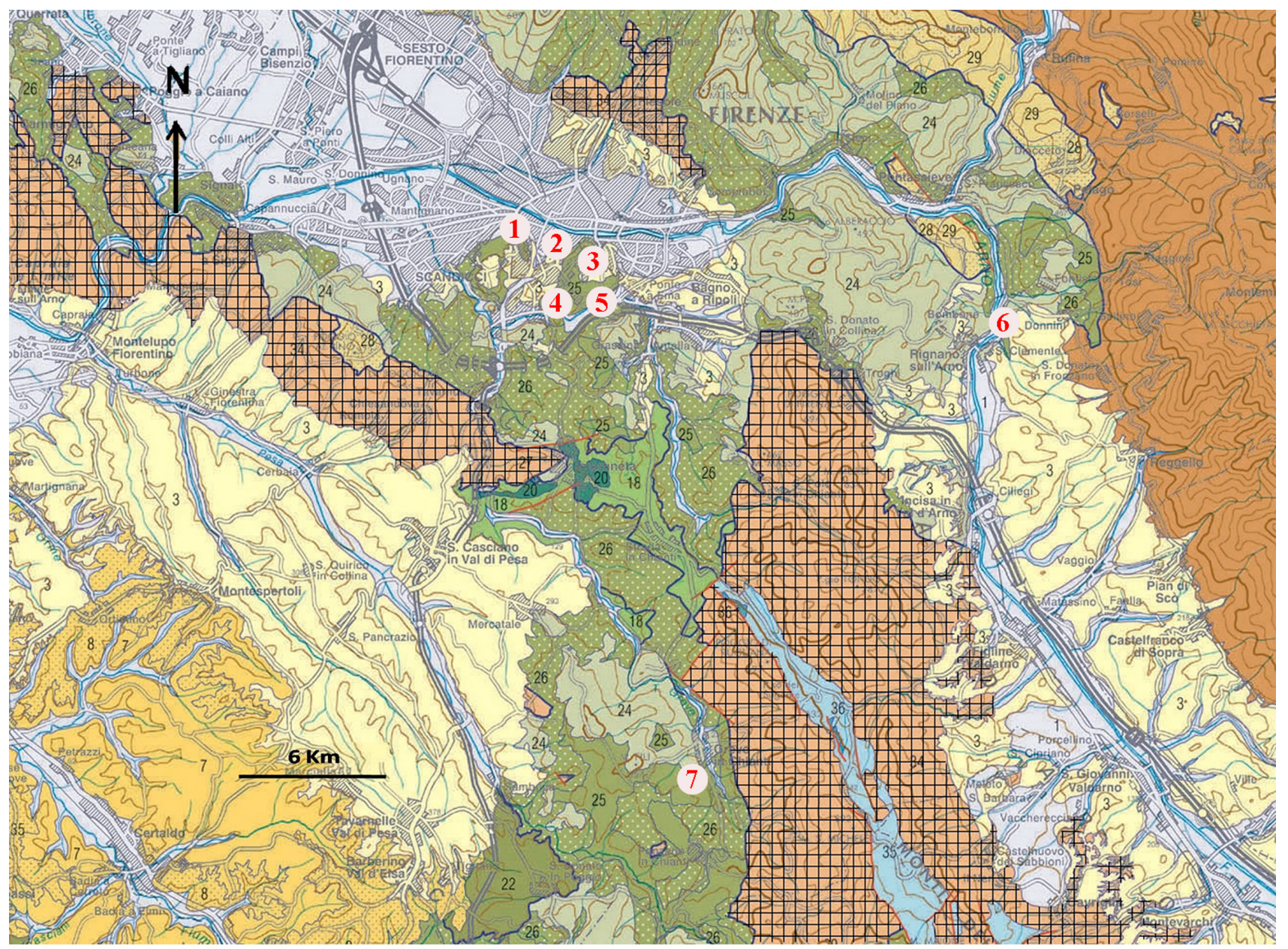

1 Alluvial deposits (Late Quaternary)

3 Conglomerates, sands, silts, clays and limestones (Ruscinian - Villafranchian)

7 Clays, silty and marly clasys (Pliocene)

8 Conglomerates, sandstones, bioclastic limestones (Pliocene)

18 Shales, calcilutites, siltstones of the Caotic Complex (Cretaceous)

20 Ophiolitic Complex (Jurassic)

22 Helmitoides flysh (Late Cretaceous - Paleocene)

24 Monte Morello Formation - “Alberese" (Late Cretaceous - Middle Eocene)

25 Pietraforte Formation (Late Cretaceous)

26 Sillano Formation (Cretaceous - Paleocene)

28 Monte Senario sandstones Formation (Eocene - Oligocene)

29 Shales and limestones of Canetolo Unit (Paleocene - Eocene)

32 M. Cervarola sandstones (Chattian - Langhian)

34 Macigno Formation and Monte Modino sandstones Formation (Oligocene - Early Miocene)

35 Scaglia Toscana Formation (Early Cretaceous - Oligocene)

36 Maiolica Formation and jaspers formation (Early Liassic - Early Cretaceous)

Figure 2. Geological map of the outskirts of Florence with the locations of the ancient Pietraforte quarries (geological map 1:250.000 modified after Carmignani et al. 2004): 1 = Bellosguardo quarry; 2 = Boboli quarry; 3 = viale Galileo quarry; $4=$ Monteripaldi quarry; $5=$ Ema valley quarries; $6=$ Riscaggio quarry; 7 = Greve quarry. 

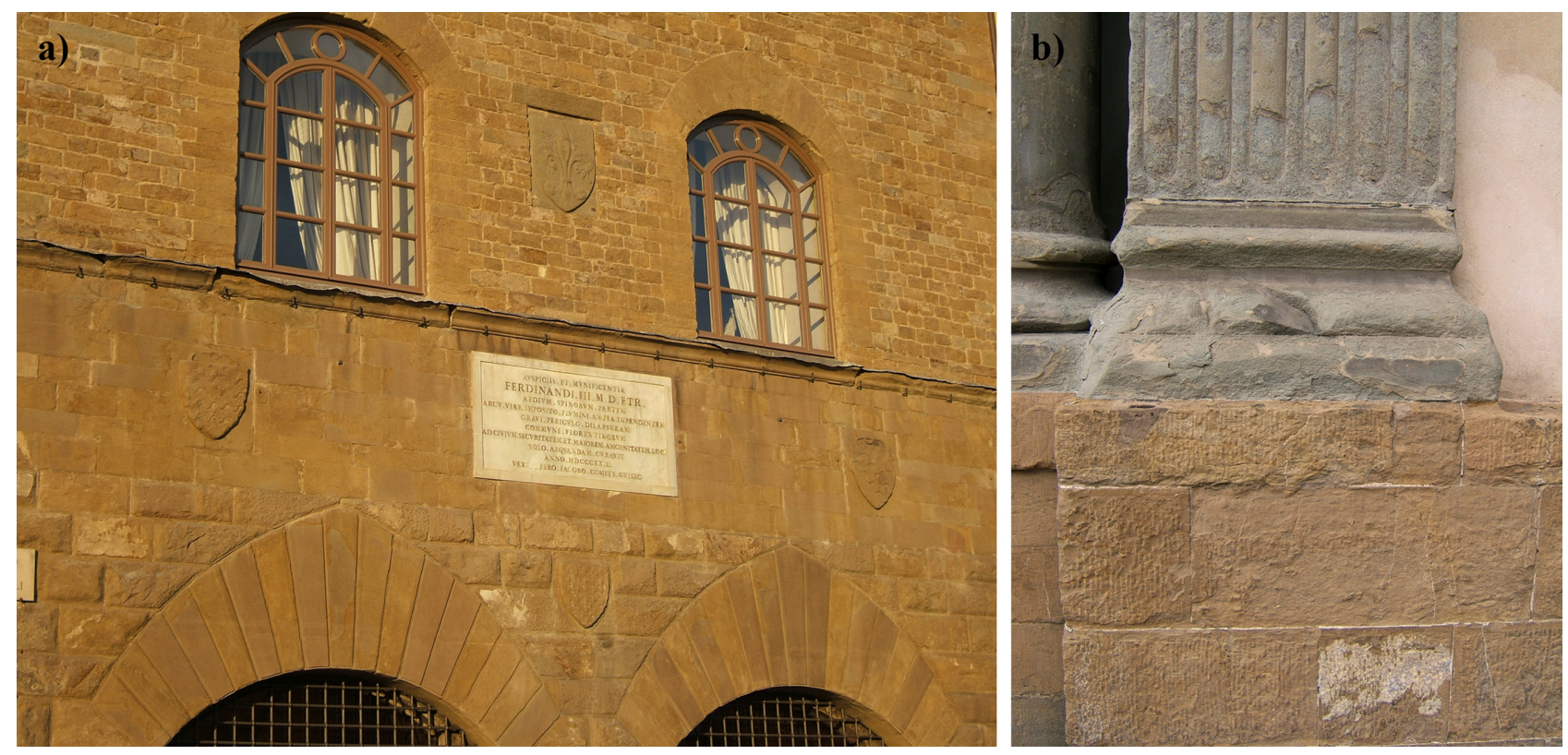

Figure 3. a) Palazzo Spini Feroni built at the end of the XIII ${ }^{\text {th }}$ century, one of the best examples of medieval residential architecture in Florence; b) pedestal of the Spedale degli Innocenti, designed by Brunelleschi in the first half of the XV $V^{\text {th }}$ century, one of the most representative buildings of the Renaissance: below is Pietraforte with its ochraceous shade, above the pilaster in Pietra Serena with its cerulean colour.

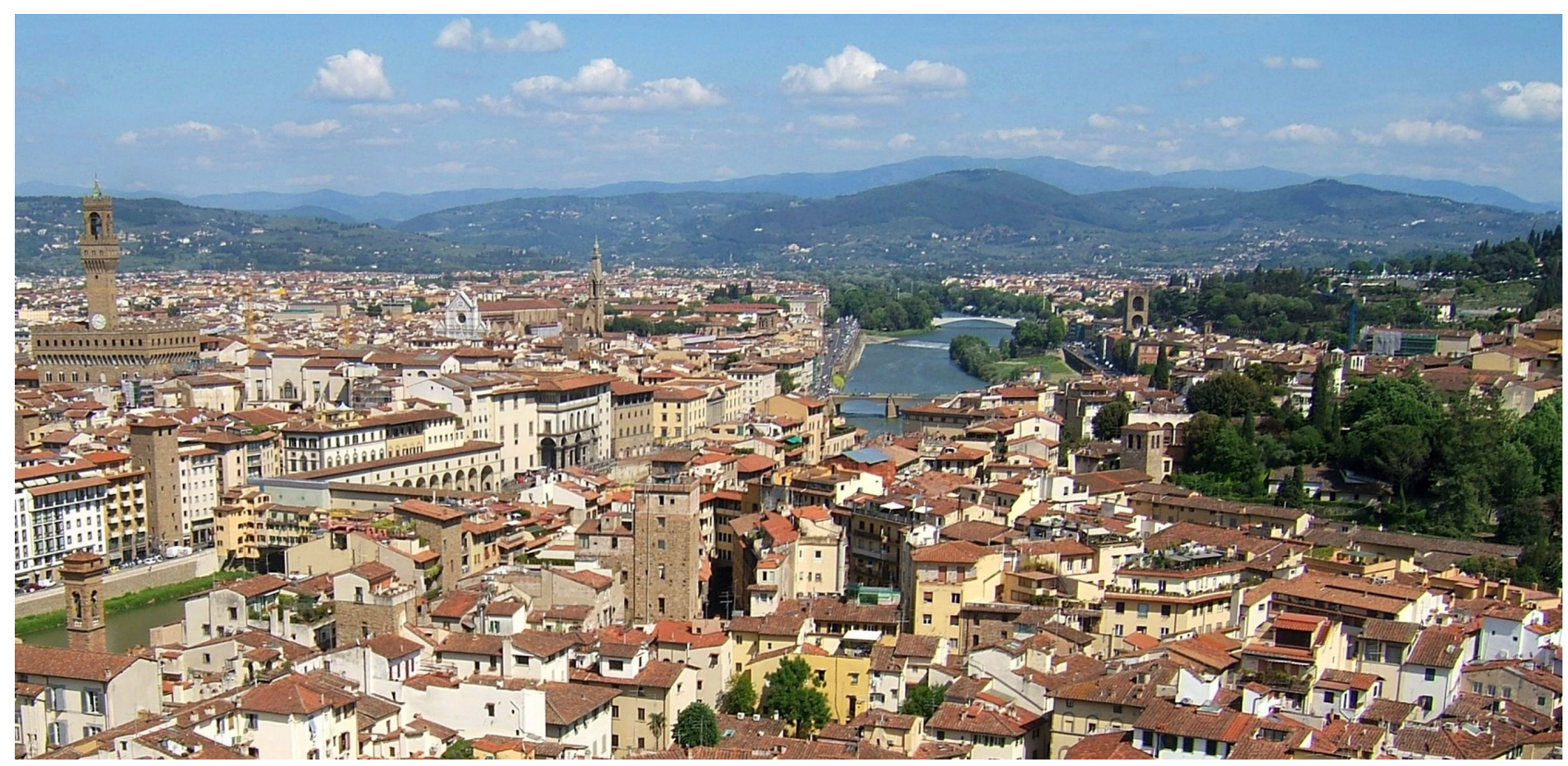

Figure 4. View of Florence from the bell tower of Chiesa di Santo Spirito: on the right, close to the river Arno, the hills from where the Pietraforte sandstone was extracted during Middle Age.

of Pietraforte was the most eastern part of the Ligurian oceanic realm close to the Tuscan sector of the Adriatic margin (Abbate et al., 1986; Sestini et al., 1986; Abbate et al., 1994). The Pietraforte beds are made up of graded turbiditic sandstones that are characterized inside by Bouma intervals of which plane parallel, undulated and convoluted current laminations (Fig. 8) ("b" and "c" interval) are well represented. Particularly the "c" interval, produced by the action of currents and by the ensuing discharge of water during diagenetic burial (Ricci Lucchi, 1972, 1976), is a typical feature in the Pietraforte ashlars of some Renaissance buildings (see this detail in Palazzo Rucellai - Fig. 8).
The sandstone has a lithic composition characterized by sedimentary rock fragments, feldspars (mainly plagioclases) and a high content of quartz. Carbonatic rock fragments are prevalent, consisting of dolostone and a wide variety of limestones from micritic to sparitic. The paleocurrent structures (groove and flute casts) show an overall dispersion of the turbiditic flows from NW to NE quarters, but also western sources are described by Bortolotti (1967) and Abbate and Sagri (1970). Therefore, the main source areas of the turbiditic flows of the Pietraforte sandstone can be identified in the northern margin of the Adriatic plate, mostly from the Palaeozoic low-grade metamorphic 


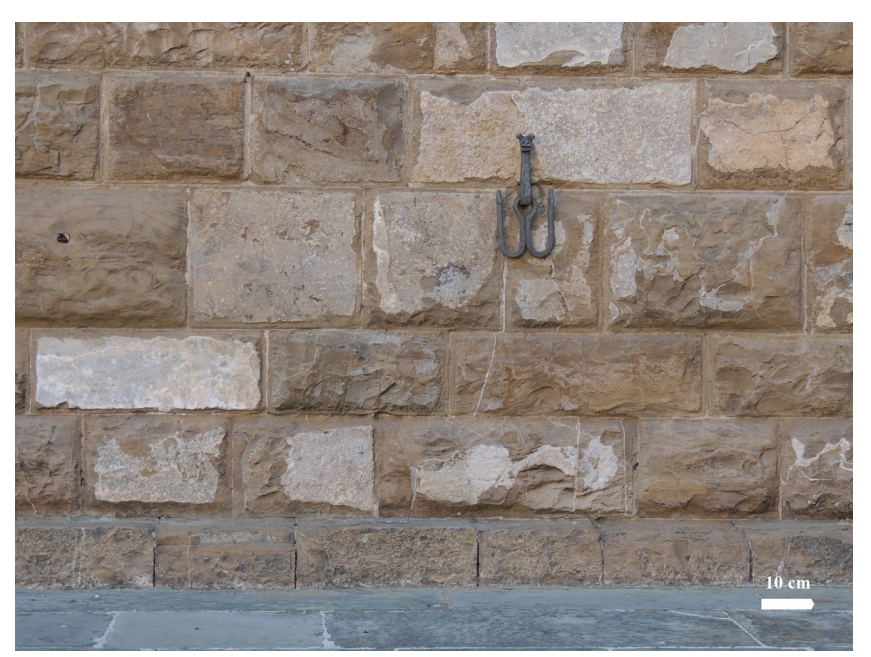

Figure 5. Particular of the old nucleus of Palazzo Vecchio (first half of the XIV ${ }^{\text {th }}$ century). The whitish surface of some Pietraforte ashlars represent original fractures filled by calcite, which favoured the shaping of the stone.

basement and its sedimentary and volcanic cover formations of the South Alpine area (Cipriani and Malesani, 1966; Bortolotti and Malesani, 1967; Cipriani et al., 1976; Sestini et al., 1986). Other authors have alternately suggested, a source from the Tuscan Domain (Fontana and Mantovani Uguzzoni, 1987; Fontana, 1991).

In addition to the outcrops of Pietraforte Formations in the surroundings of Florence, other important outcrops of Pietraforte are located to the NW (Calvana and Monte Morello areas), east (Riscaggio on the western slopes of Pratomagno close to Reggello), south of Florence (Chianti area), in Casentino Valley (eastern Tuscany) and in the southernmost part of the region (Montalcino and around Monte Amiata). Outside Tuscany, other outcrops are those of the Monti della Tolfa
(Northern Latium), Val Marecchia (Marche Region) and Monte Barigazzo (Emilian Apennine).

From the lithological point of view, the Pietraforte Formation is generally represented by pelitic-arenaceous, and locally also by arenaceous-pelitic facies. They consist of a regular alternation of gradedmedium to fine, at times coarse-grained, silicic-carbonate turbiditic sandstones with Tb-e, Tc-e, Td-e and Ta-e Bouma's intervals, and siltymarly shales (traditionally called bardellone). Some horizons of varicoloured shales, marls and more or less marly limestones can be present particularly in the lower and upper parts of the formation. The thickness of the beds is generally decimetric $(10-40 \mathrm{~cm}$, up to $80 \mathrm{~cm}$ thick), but rarely are about $1 \mathrm{~m}$ thick or more (Fig. 9). Centimetric - to decimetric thick horizons of microconglomerates (cicerchina Auctt.) can be locally recognized at the base of the thickest and coarser beds that locally show discontinuous crude laminations. Arenaceous-pelitic, arenaceous successions with Ta-e, Ta/c-e, Tab/de, Ta/de beds up to conglomeratic facies are present in the southern outcrops too, e.g. of the Monte Amiata area (Bortolotti, 1962, 1963; Pandeli et al., 2005; Marroni et al., 2015).

\section{Materials and Methods}

In Table 1 the list and the number of the samples collected from the most ancient quarries and from some historical buildings of Florence is reported (Fig. 1).

The petrographic observations were carried out on three representative samples for each quarry and historical building by means of a ZEISS Axio Scope. A1 microscope, with videocamera, resolution 5 Megapixel and image analysis software AxioVision.

X-ray Diffraction (Philips PW 1050/37 powder diffractometer with a $\mathrm{Cu}$ anode and graphite monochromator) operating at $40 \mathrm{kV}, 20 \mathrm{~mA}$, with $2 \%$ min goniometry speed, investigated range $2 \theta=5-70^{\circ}$ on bulk

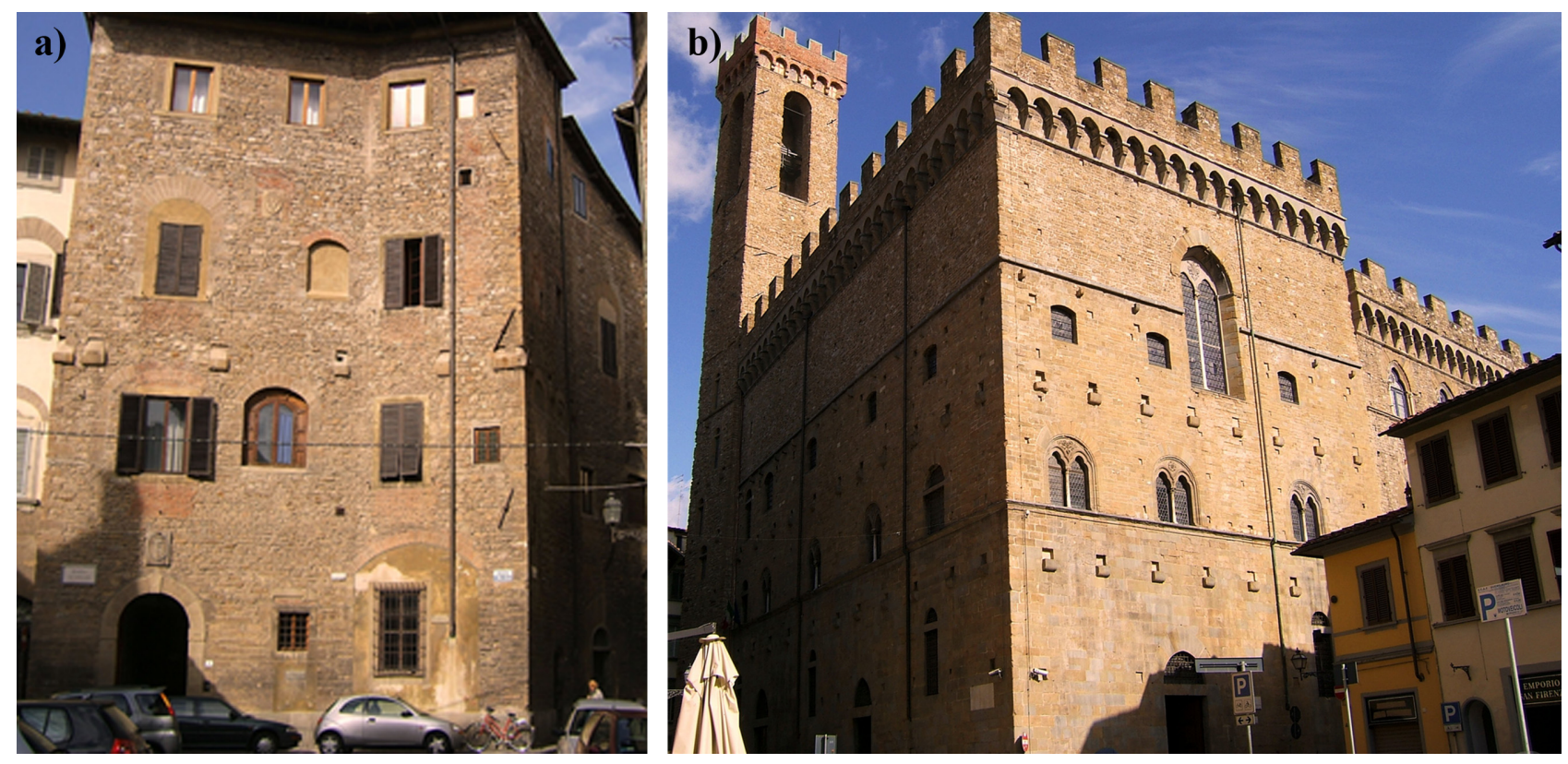

Figure 6. a) Tower house made of Pietraforte, in Piazza Peruzzi; b) Palazzo del Bargello, in the image can be seen the first nucleus of the palace (half XIII ${ }^{\text {th }}$ century), built with partial shaped Pietraforte blocks. 

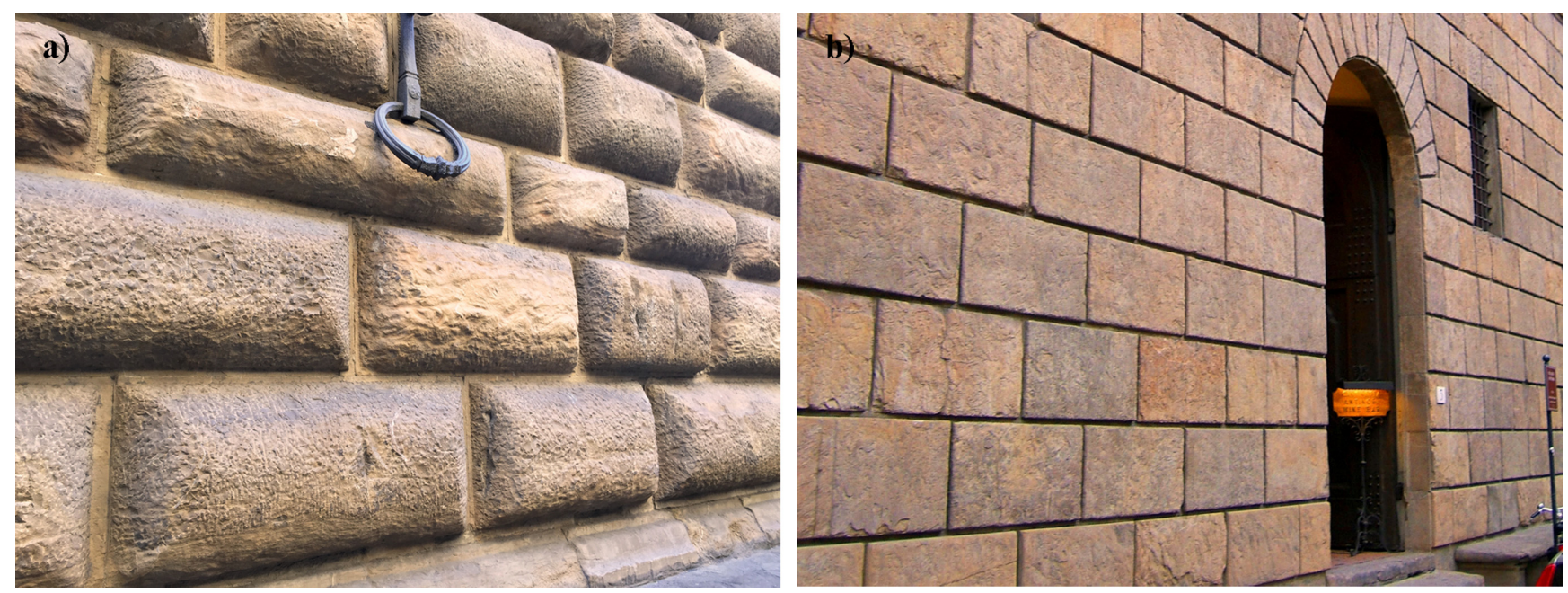

Figure 7. a) Palazzo Strozzi (beginning XVI' century), example of late Renaissance architecture, with a façade in Pietraforte quarry-faced ashlars (bugnato rustico); b) Palazzo Antinori (XV th century) with the façade in bugnato liscio.

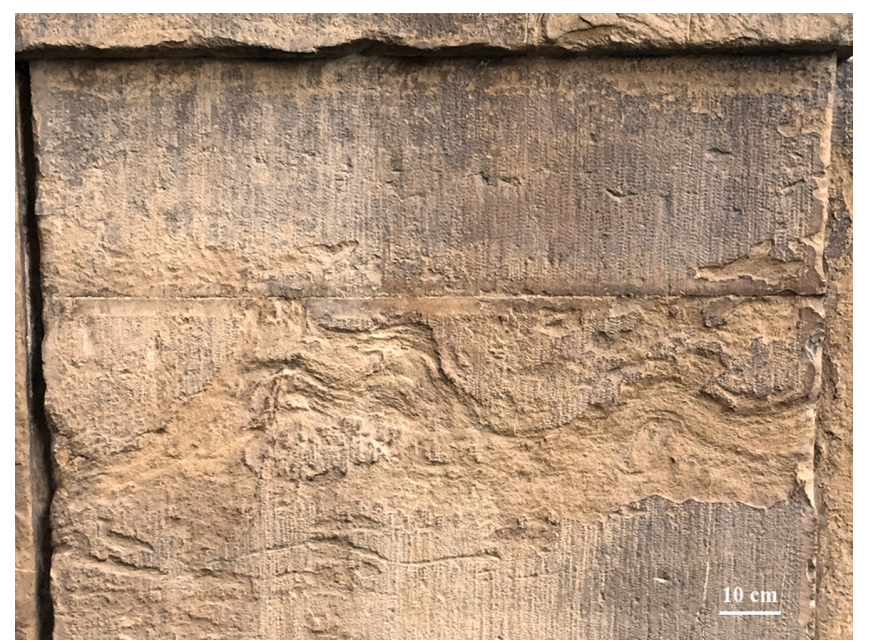

Figure 8. Convolute laminations in the Pietraforte of Palazzo Rucellai (XVIth century).

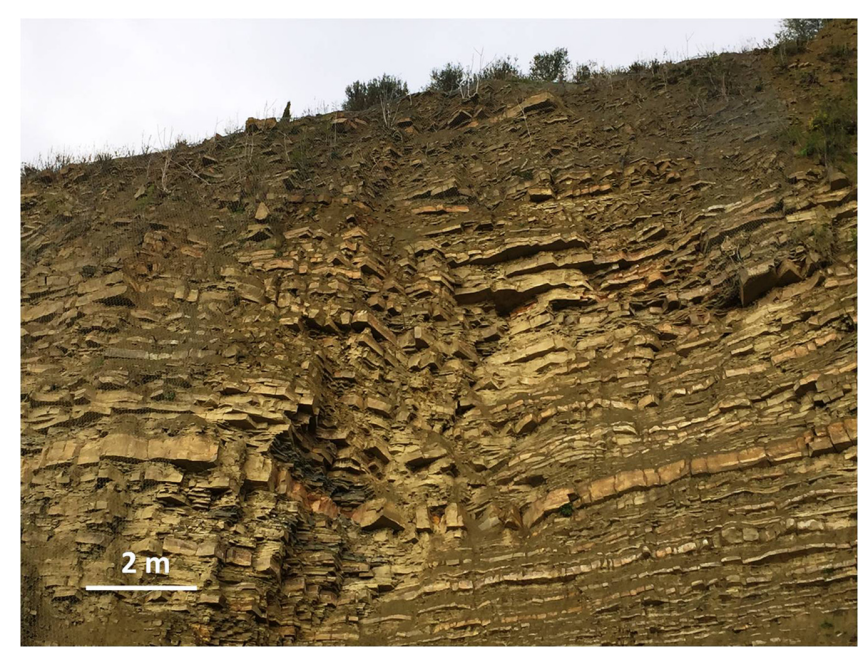

Figure 9. The Monteripaldi quarry, on the hills along Ema valley, south of Florence.
Table 1. Pietraforte stone samples of the most ancient quarries and historical buildings of Florence

\begin{tabular}{cc}
\hline \hline Pietraforte quarries & Historical buildings \\
\hline Viale Galileo* & Palazzo Uguccioni \\
Bellosguardo & Loggia dei Lanzi \\
Greve & Palazzo Pitti \\
Riscaggio & Palazzo Gondi \\
Boboli & Palazzo Strozzi \\
Monteripaldi & Palazzo Antinori \\
& Palazzo Rucellai \\
& Palazzo Medici Riccardi \\
& Palazzo dello Strozzino \\
\hline
\end{tabular}

*Five samples for both quarries and historical buildings have been collected

samples and $5-32^{\circ}$ on the clay fraction $<4 \mu \mathrm{m}$ (Cipriani, 1958a, b; Cipriani and Malesani, 1972), was used for the mineralogical analyses carried out on five samples for each ancient quarry and for each historical building. X'Pert PRO and High Score software for data acquisition and data interpretation were used.

The physical characterization of the Pietraforte was performed on the material coming from the quarries of Monteripaldi and Riscaggio, the only quarries that were able to provide sufficient material for the analyses. For each quarry five specimens were tested.

Samples of size $1.5 \times 1.5 \times 3 \mathrm{~cm}$ were dried at $60^{\circ} \mathrm{C}$ and the dry weight $\mathrm{W}_{\mathrm{d}}$ was determined. The real volume $\mathrm{V}_{\mathrm{r}}$ and the bulk volume $\mathrm{V}_{\mathrm{b}}$ were determined using, respectively, a Quantachrome helium pycnometer and a Chandler Engineer mercury pycnometer. Then the samples were dipped into deionised water and weighed after saturation (constant wet weight $\mathrm{W}_{\mathrm{w}}$ ). With these data the following parameters have been determined:

- real density $(\gamma),=\mathrm{W}_{\mathrm{d}} / \mathrm{V}_{\mathrm{r}}$;

- bulk density $\left(\gamma_{\mathrm{s}}\right)=\mathrm{W}_{\mathrm{d}} / \mathrm{V}_{\mathrm{b}}$;

- total open porosity $\mathrm{P} \%=\left(\mathrm{V}_{\mathrm{b}}-\mathrm{V}_{\mathrm{r}}\right) / \mathrm{V}_{\mathrm{b}} \cdot 100$;

- water imbibition coefficient $\mathrm{IC}_{\mathrm{w}} \%$, (expressed in weight) 
$=\left(\mathrm{W}_{\mathrm{w}}-\mathrm{W}_{\mathrm{d}}\right) / \mathrm{W}_{\mathrm{d}} \cdot 100$

- water imbibition coefficient $\mathrm{IC}_{\mathrm{v}} \%$, (expressed in volume)

$=\mathrm{IC}_{\mathrm{w}} \cdot \gamma_{\mathrm{s}} \cdot 100$;

- water saturation index $\mathrm{SI} \%=\mathrm{IC}_{\mathrm{v}} / \mathrm{P} \cdot 100$.

The porosity in the range $0.0037-150 \mu \mathrm{m}$ (mesoporosity) and the relative pore size distribution were determined with a Thermo Quest mercury porosimeter utilising different pressure systems (Pascal 140 and 240). The mesoporosity together with the total open porosity made it possible to calculate, as a difference, the microporosity (pores with radius $\leq 0.0037 \mu \mathrm{m}$ ), according to the classification of pore space proposed in Barsottelli et al. (1998), Barsottelli et al. (2001) and Cantisani et al. (2009).

\section{Pietraforte Description}

\section{Petrographic characterization}

Pietraforte is defined petrographically as lithic sandstone according to Dickinson (1970), Folk (1974), Fontana (1991) and Valloni and Zuffa (1984) (see Fig. 10a). This stone has a clastic component made of quartz, feldspars, carbonate grains and fragments of sedimentary, low-grade metamorphic and acidic effusive rocks. The binder consists of recrystalized micritic calcite, a little amount of clay minerals and a secondary calcite cement. (Fig. 10b) (Cipriani and Malesani, 1966; Fontana, 1991).

Cipriani and Malesani (1966) highlighted in the Pietraforte Formation the high content of quartz ( $\sim 3 \%$ on the average) present as single granules, quartz inside metamorphic fragments, cherts and neoformed quartz (diagenetic). In particular, the analyses performed by Cipriani and Malesani (1966) and Fontana (1991) in the thicker medium to coarse-grained arenaceous beds in the Florence area, reveal that the silicatic components (average $\sim 56 \%$ ) generally have more or less the same abundance of the carbonatic ones (average 44\%). The carbonatic components are mostly of clastic origin (max $25 \%$ ) and the dolomitic component largely prevails over the calcitic one (generally 2 to $8 \%$ ).

The monocrystalline grains are made up of: quartz (generally 13-
$21 \%$ ) characterized mostly by a sharp extinction; feldspars at $<4 \%$ and represented essentially by acidic plagioclases often with calcite alterations; micas (mainly muscovite) at $<4 \%$; carbonates ( $2-8 \%$ ) which are essentially dolomitic.

The lithic component ( $45 \%$ on the average) consists of:

- sedimentary rocks (average 24\%): dolostone prevalent on limestone, cherts/radiolarites, shales, marly shales and siltstone/fine grained sandstone. Fontana and Mantovani Uguzzoni (1987) distinguished extra and intra basinal carbonate clasts with Late Triassic to Cretaceous microfacies;

- metamorphic rocks (average 11\%): sericitic and chloritic phyllites and quartzites, micaschists and minor gneiss;

- volcanic rocks (average 10\%): rhyolite and rhyodacite with quartz and plagioclase phenocrysts and often with recrystallized glassy groundmass sometimes with flow textures. Accessory minerals are: tourmaline, zircon, rutile, garnet, magnetite and pyrite.

Bioclasts are relatively common (average $\sim 4 \%$ ): ammonites, Inoceramus, calcareous algae (Lithotamnium), rudists, bryozoa, bivalves, planktonic and benthonic foraminifera of Late Cretaceous age (generally Turonian-Maastrichtian).

The relevant part of calcite is related mainly to the recrystallized carbonatic matrix and also to the secondary calcite cement, overall for an average $20 \%$. The original micritic carbonates of the matrix underwent recrystallization during diagenesis, forming a resistant binder. The clay matrix (average $\sim 6 \%$ ) generally occurs as pseudo matrix due to the alteration of the pelitic lithics. The packing of the granular framework is middle to high.

The sandstone is grey when fresh, but easily undergoes chromatic alteration by weathering, acquiring a warm ochre/yellowish colour. This colour change, due to iron oxidation, proceeds very quickly from the surface to the inner part of the beds without causing a decrease of cohesion in the arenitic framework (Malesani et al., 2003). Nevertheless, some areas retain the grey colour for centuries (Fig. 11).

Pietraforte in addition to the plane-parallel and convoluted laminations, presents fractures which are completely or partially filled with calcite (calcite veins), which represents a factor of weakness due to preferential separation. a)

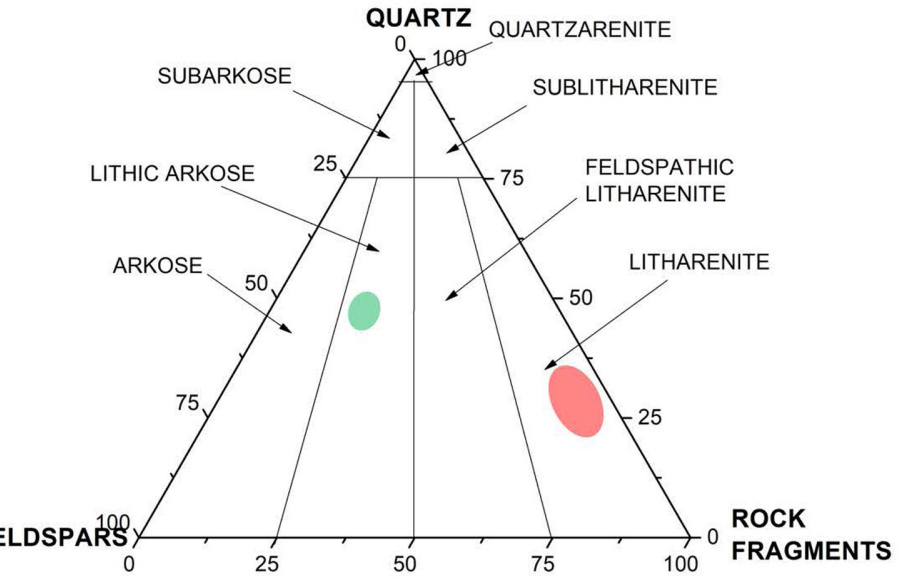

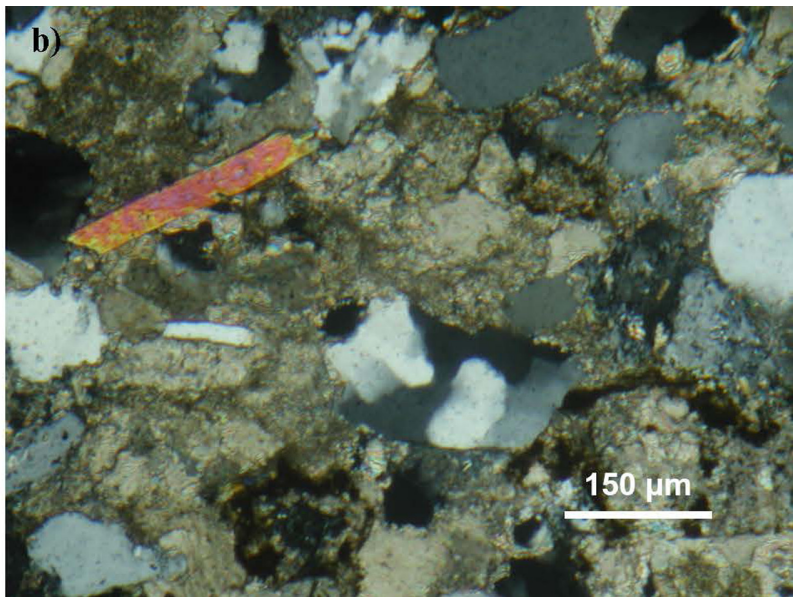

Figure 10. a) Ternary diagram (quartz, feldspars, rock fragments- modified after Folk, 1974) representing the petrographic classification fields of Pietraforte (violet) compared to Pietra Serena (green); b) thin section photomicrograph of Pietraforte sandstone: here is visible the clastic fraction made of quartz, micas, dolomite rock fragments and the matrix made of the micritic carbonates mixed with clay minerals (transmitted light, xpl). 


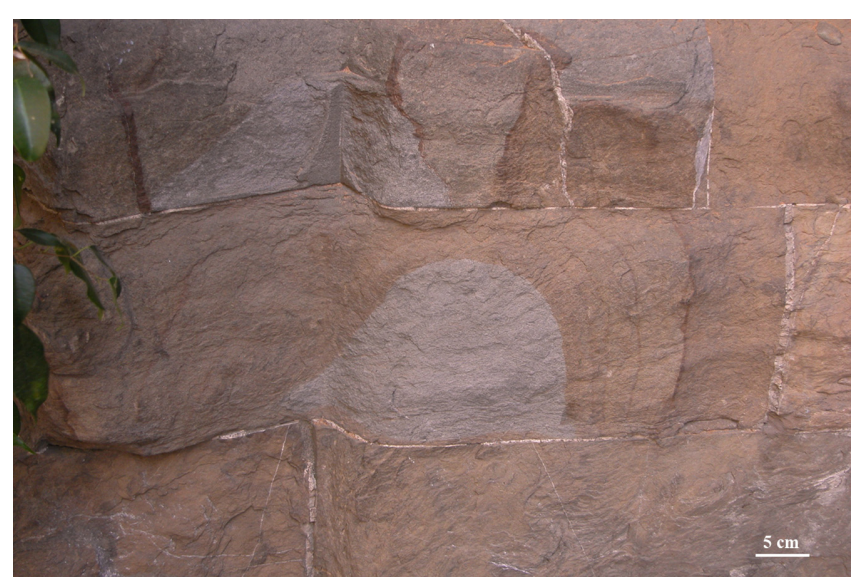

Figure 11. Portion of Pietraforte showing inside the original grey colour.

\section{Mineralogical characterization and provenance of sandstone}

As previously stated, the most ancient quarries of Pietraforte, as reported in Fig. 2, were located close to the left bank of the Arno river, namely where now the Chiesa di S. Felicita is sited, and on the nearby hill of Costa San Giorgio- Forte Belvedere). Also, the present site of Palazzo Pitti was a quarry together with a part of the Giardino di Boboli, laid out at the site of different quarries, being an example of splendid ante-litteram landscape recovery (Fig. 12).

Over the centuries, the expansion of the city has suffered the progressive obliteration of these quarries, due to political and territorial reasons, while others were opened further south (Monteripaldi, Ema valley) (Pampaloni, 1974) (cfr. Fig. 2). A quarry in the hills west of Porta Romana (Bellosguardo) provided the material for Santa Maria Novella railway station (Conforti et al., 2016), while a quarry was reopened in Boboli to provide material for the restoration and rebuilding the ancient Oltrarno, Por Santa Maria and Borgo S. Apostoli buildings after their destruction in 1944 during the Second World War. In the second half of the $\mathrm{XX}^{\text {th }}$ century, the last exploited quarries were those of Greve (Montepomino and Santa Cristina, $20 \mathrm{~km}$ south of Florence) and Riscaggio, municipality of Reggello (20 km east of Florence) (Fig. 2). The Greve quarry has now been definitively closed, while the Riscaggio quarry is still open. A lithotype similar to Pietraforte is that of some more calcareous beds named Colombino present within the Marnoso Arenacea siliciclastic turbiditic formation exploited in the surrounding of Firenzuola, $50 \mathrm{~km}$ north of Florence, along the Apennine ridge (Cantisani et al., 2013).

The location of the quarries that provided the stone utilized in the monumental architecture is very important both in the historicalarchitectonical study and in the restoration of monuments in order to understand the alteration processes. For instance, in the case of marble, many parameters can be defined like isotopic ratios $\delta^{13} \mathrm{C}-\delta^{18} \mathrm{O}$ and electron spin resonance spectroscopy (ESP) allowing a reliable identification of the source areas (Attanasio et al., 2000).

For the Pietraforte quarries, among the several parameters considered, the paragenesis of the clay minerals was the parameter that our research group selected as being the more reliable to distinguish, the different historical quarries and probably even some quarried outcrops along the Viale Galileo, that supplied Florence (Banchelli et al., 1997).

The Banchelli's data were implemented with new samples from Viale Galileo, Greve, Riscaggio, Boboli and Monteripaldi. Besides another Florentine quarry, Bellosguardo, was analysed.

The mineralogical data for bulk samples are the same for all the quarries: quartz, calcite, dolomite, acidic plagioclases and phyllosilicates, while the composition of the clay minerals association is summarized in Figure 13, from which it is possible to highlight how the differences are related to the presence/absence of kaolinite, chlorite and illite/smectite.

At first a confirmation of the reliability of the method used to identify different quarries came from the study of the Pietraforte ashlars of Palazzo Uguccioni in Piazza Signoria (XVI ${ }^{\text {th }}$ century). Uguccioni family owned estates around Monteripaldi where several abandoned quarries are located and our analysis pointed to a provenance of the

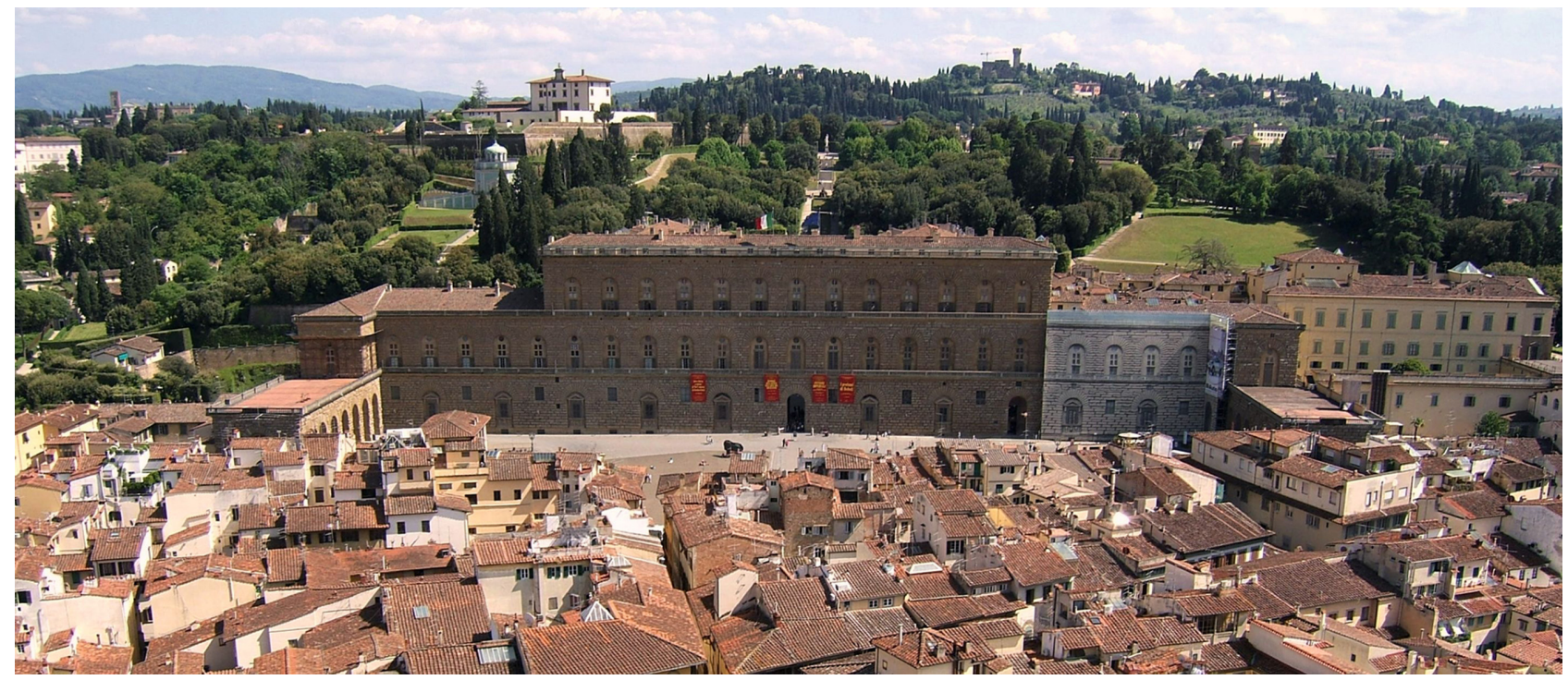

Figure 12. Palazzo Pitti (XV $V^{\text {th }}$ XIX ${ }^{\text {th }}$ century) seen from the bell tower of nearby Chiesa di Santo Spirito: at the back is the Giardino di Boboli, laid out within the site of a Pietraforte quarry. 
Viale Galileo

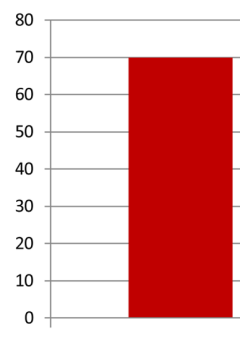

ilt

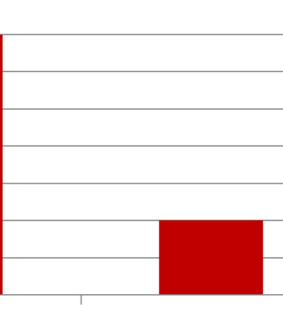

$\mathrm{chl} / \mathrm{vrm}$

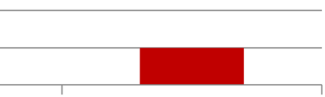

ilt/sme

Greve

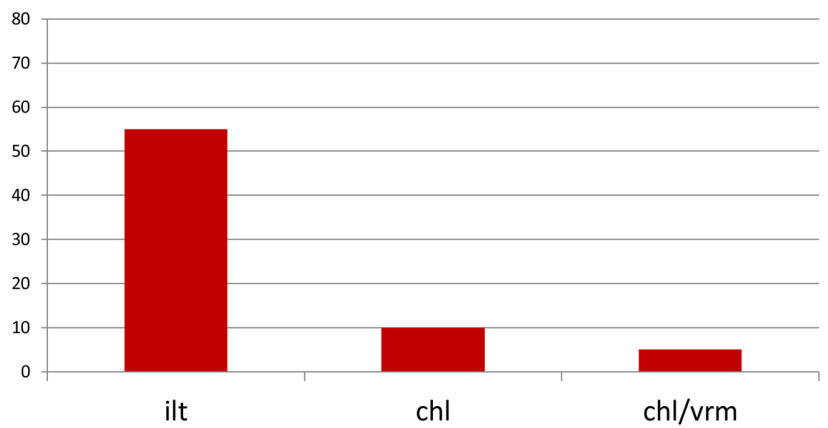

Boboli

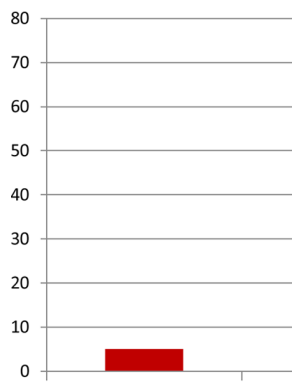

$\mathrm{kln}$

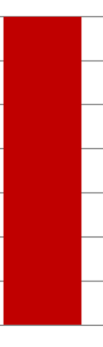

ilt

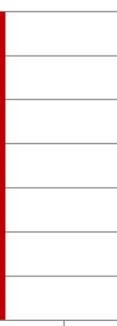

$\mathrm{chl} / \mathrm{vrm}$

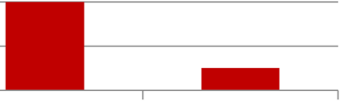

ilt/sme

\section{Bellosguardo}

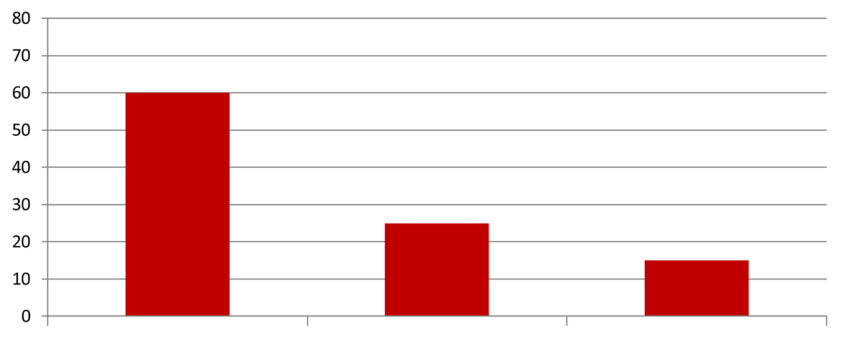

ilt

$\mathrm{chl} / \mathrm{vrm}$

Riscaggio

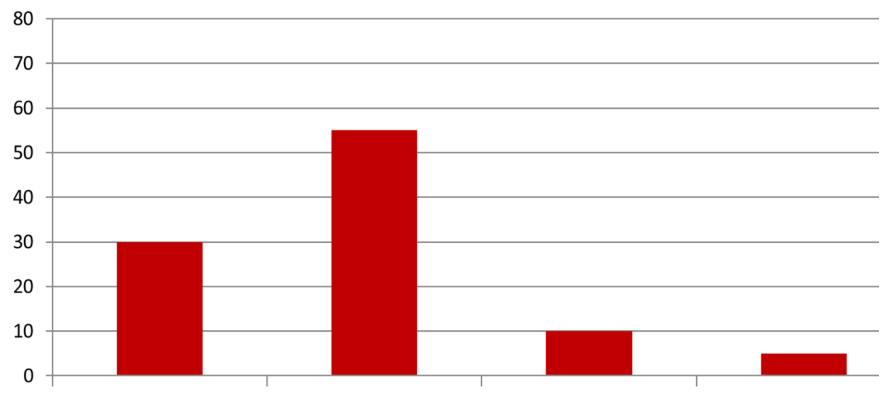

kln

ilt

chl

$\mathrm{chl} / \mathrm{vrm}$

Figure 13. Composition of the mineral clay associations for different Florentine ancient quarries (ilt = illite; chl = chlorite; vrm = vermiculite; sme = smectite; $\mathbf{k l n}=$ kaolinite; ilt/sme = illite/smectite; $\mathrm{chl} / \mathrm{vrm}=$ chlorite/vermiculite). The differences are related to the presence/absence of kaolinite, chlorite and illite/smectite.

ashlars of this palace from that area. The clay minerals analysis provided interesting information also for the Loggia dei Lanzi. Indeed, material from three different localities (Boboli, Monteripaldi and Viale Galileo area) was highlighted. In particular, the material of the upper part of the Loggia dei Lanzi comes from Monteripaldi, even though this quarry was opened at the end of the $\mathrm{XV}^{\text {th }}$ century and the period of construction of the Loggia is the XIV ${ }^{\text {th }}$ century. A possible explanation is that the upper part of the building, being more exposed to the atmospheric agents, has undergone periodic substitutions with material coming from Monteripaldi. As for Palazzo Pitti, the materials of the oldest part of the building (XVI ${ }^{\text {th }}$ century) come from the quarries that were located in the nearby Giardino di Boboli, while the more recent south and north wings (second half of the XVIII ${ }^{\text {th }}$ century) were realized with material coming from Monteripaldi.

Also, for Palazzo Gondi the variability of clay mineral composition is in accordance with the different construction phases. In fact, the building was designed by Giuliano da Sangallo in 1490, but it was enlarged in 1870 following the demolition of a nearby building. The analysis, in fact, has shown that the ashlars of the oldest part come from the quarries of Boboli while those of the added part are from Monteripaldi. Analyses have been carried out also for Palazzo Strozzi, Antinori, Medici Riccardi, Rucellai and Strozzino. Also, for these buildings the original supply quarries were located in Boboli, but for Palazzo Strozzi the partial substitutions of the ashlars carried out in 1937, with material coming from Monteripaldi have been highlighted. Table 2 summarizes the results of the Pietraforte provenance of the historical buildings in Florence.

\section{Physical characterization}

The physical data of the sandstone coming from Monteripaldi and Riscaggio quarries, are similar; they show a low total open porosity, more than a half of this porosity being represented by mesopores. The latter favours the absorption and retention of liquid water as demonstrated by a quite high saturation index (SI) (Table 3) (Cantisani et al., 2009). Nevertheless, it must be considered that the presence of swell- 
Table 2. Clay minerals association and quarries provenance of some historical buildings in Florence

\begin{tabular}{|c|c|c|}
\hline Historical buildings & Clay minerals association & Ancient quarries \\
\hline Palazzo Uguccioni & kln, ilt, chl, chl/vrm & Monteripaldi \\
\hline Loggia dei Lanzi & $\begin{array}{l}\mathrm{kln}, \mathrm{ilt}, \mathrm{chl} / \mathrm{vrm}, \mathrm{ilt} / \mathrm{sme} \\
\mathrm{kln}, \mathrm{ilt}, \mathrm{chl}, \mathrm{chl} / \mathrm{vrm} \\
\text { ilt, chl/vrm, ilt/sme }\end{array}$ & Boboli, Monteripaldi Viale Galileo \\
\hline Palazzo Pitti & $\begin{array}{l}\mathrm{kln}, \mathrm{ilt}, \mathrm{chl} / \mathrm{vrm}, \mathrm{ilt} / \mathrm{sme} \\
\text { kln, ilt, chl, chl/vrm }\end{array}$ & Boboli Monteripaldi \\
\hline Palazzo Gondi & $\begin{array}{l}\text { kln, ilt, chl/vrm, ilt/sme } \\
\text { kln, ilt, chl, chl/vrm }\end{array}$ & Boboli Monteripaldi \\
\hline Palazzo Strozzi & $\begin{array}{l}\mathrm{kln}, \mathrm{ilt}, \mathrm{chl} / \mathrm{vrm}, \mathrm{ilt} / \mathrm{sme} \\
\text { kln, ilt, chl, chl/vrm }\end{array}$ & Boboli Monteripaldi \\
\hline Palazzo Antinori & kln, ilt, chl/vrm, ilt/sme & Boboli \\
\hline Palazzo Rucellai & kln, ilt, chl/vrm, ilt/sme & Boboli \\
\hline Palazzo Medici Riccardi & kln, ilt, chl/vrm, ilt/sme & Boboli \\
\hline Palazzo dello Strozzino & kln, ilt, chl/vrm, ilt/sme & Boboli \\
\hline
\end{tabular}

$\mathrm{kln}=$ kaolinite; ilt = illite; $\mathrm{chl}=$ chlorite vrm = vermiculite; sme = smectite; ilt/sme = illite/smectite; chl/vrm = chlorite/vermiculite

Table 3. Physical parameters of Pietraforte sandstone

\begin{tabular}{|c|c|c|c|c|c|c|c|c|c|}
\hline \multirow{2}{*}{ Pietraforte quarries } & \multirow{2}{*}{$\gamma\left(\mathrm{g} / \mathrm{cm}^{3}\right)$} & \multirow{2}{*}{$\gamma_{\mathrm{s}}\left(\mathrm{g} / \mathrm{cm}^{3}\right)$} & \multirow{2}{*}{$\mathrm{P}_{\mathrm{tot}}(\%)$} & \multicolumn{3}{|c|}{ Total porosity decomposition (\%) } & \multirow{2}{*}{$\mathrm{IC}_{\mathrm{W}}(\%)$} & \multirow{2}{*}{$\mathrm{IC}_{\mathrm{V}}(\%)$} & \multirow{2}{*}{$\mathrm{SI}(\%)$} \\
\hline & & & & Micro & Meso & Macro & & & \\
\hline Monteripaldi & $2.70 \pm 0.01$ & $2.57 \pm 0.01$ & $5.60 \pm 0.14$ & $2.60 \pm 0.01$ & $3.0 \pm 0.01$ & - & $1.79 \pm 0.02$ & $4.59 \pm 0.06$ & $82 \pm 1.41$ \\
\hline Riscaggio & $2.71 \pm 0.01$ & $2.56 \pm 0.01$ & $5.70 \pm 0.14$ & $2.70 \pm 0.01$ & $3.00 \pm 0.01$ & - & $1.80 \pm 0.03$ & $4.60 \pm 0.07$ & $83 \pm 1.51$ \\
\hline
\end{tabular}

ing clay minerals (chlorite-vermiculite, illite-smectite) also contribute to increase the SI value.

About the mechanical characteristics, it should be noted that the compressive strength performed normal to the stratification is an average of $140 \mathrm{MPa}$, as reported in Pecchioni et al. (2012).

\section{Problems of conservation}

The turbiditic genesis, the petrographic and physic mechanical characteristics strongly affect the decay phenomena of Pietraforte sandstone in the Florentine architectural heritage. The typical convolute laminations of Bouma's "b" and "c" intervals, particularly evident in the upper portion of the Pietraforte beds, determines delamination and spalling in numerous ashlars. The presence of a large number of fractures and veins filled entirely or partially with calcite represents zones of preferential detachment in the blocks. Moreover, meteoric waters act on these fractures and veins both through dissolution of the calcium carbonate and through freeze-thaw phenomena. In both cases, these discontinuities are accentuated, causing the detachment of flakes and fragments. In the presence of overhanging architectural elements such as string courses, lintels and ashlars (bugnato rustico) a dangerous detachment of large portion of stone blocks can occur (Fig. 14a). On the other hand, the presence of a large amount of calcite in the matrix, which underwent a process of recrystallization during diagenesis, forming a very resistant binder, in addition to the calcite cement of secondary precipitation within the original porosity, implicate a strong cohesion of Pietraforte ashlars (compare mechanical data).

The main physical parameters (i.e. porosity and saturation index) affect the retention of water inside the pores, favouring both mechanical (freezing-thaw stress) and chemical (dissolution, hydrolysis, bio- logical grow) decay phenomena.

The water also acts on the upper portions of the ashlars, more fine and rich in clay minerals and plain/convolute laminations, with leaching/swelling of the clay minerals, favouring flaking and intergranular decohesion (Fig. 14b). The clay minerals association and the amount of swelling minerals (chlorite-vermiculite, illite-smectite) strongly influence these phenomena of decay.

\section{Conclusions}

Pietraforte is the main building material of the Medieval Florence still characterizing the city with its ochre colour. In this sense, we can really affirm that in Italy, Florence is one of the few cities mainly characterised by a single building material. This stone was used because it crops out extensively close to the city and the extraction was favoured by the suitable thickness of the arenaceous beds. This sandstone dates back to the Late Cretaceous and has a turbiditic genesis being characterized by typical convoluted laminations. During the centuries, different supplying quarries were used because the expansion of the city caused the obliteration of some quarries with the necessity to open new ones.

In this regard the possibility of recognising the source quarries of ancient buildings and monuments through the determination of the clay minerals paragenesis, can be an useful tool both for historicalarchitectonical study and for the restoration in order to understand the observed conservation conditions of the different ashlars. As for the durability of this sandstone, the results of the petrographic and physical investigations, can explain the behaviour of the material. Moreover, this can support the selection of suitable sandstones for restoration 

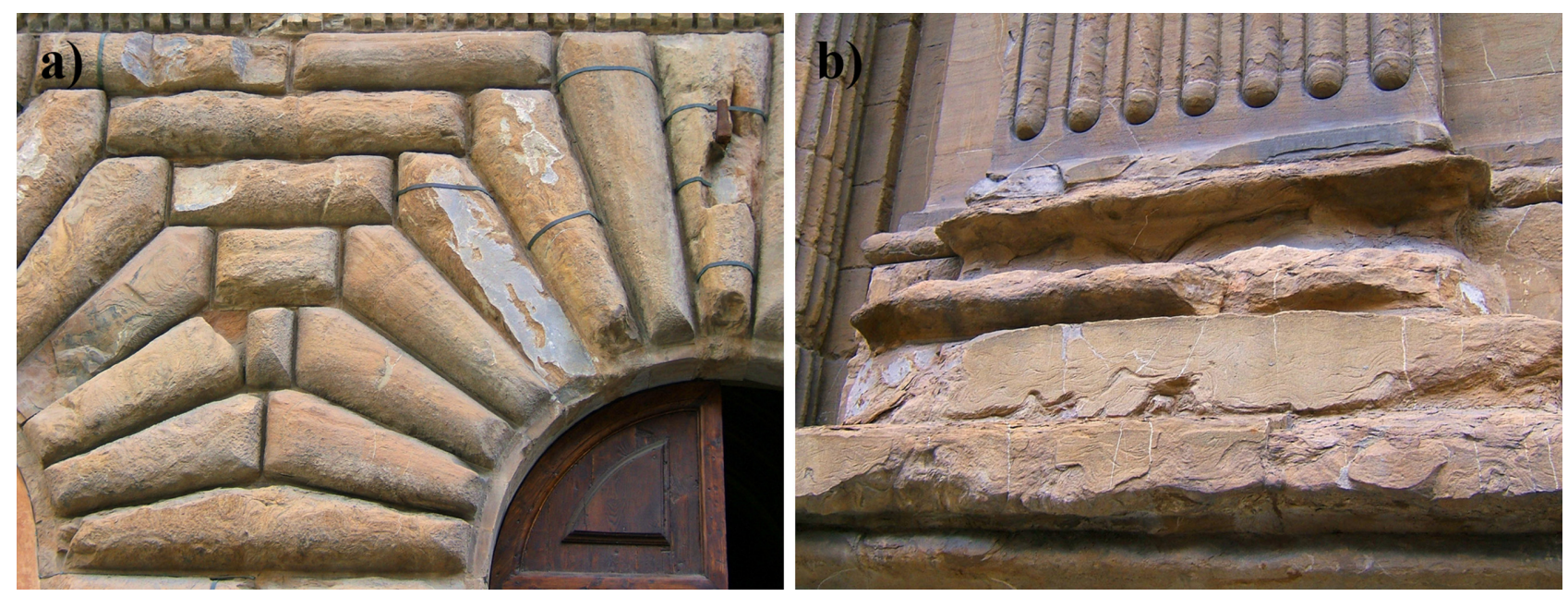

Figure 14. (a) Palazzo Uguccioni (XVI ${ }^{\text {h }}$ century), example of late Renaissance architecture: fractures and veins filled with calcite representing zones of preferential detachment in the stone blocks; (b) Chiesa di San Michele e San Gaetano (XVII ${ }^{\text {h }}$ century): flaking and intergranular decohesion in presence of plain/convolute laminations.

interventions, with aesthetical and compositional characteristics similar to original Pietraforte, also taking into account that at present only small quarries are exploited for the supplying of this sandstone (i.e., Riscaggio quarry).

\section{References}

Abbate, E., and Sagri, M., 1970, The eugeosynclinal sequences. Sedimentary Geology, v. 4, pp. 251-340.

Abbate, E., Bortolotti, V., Conti, M., Marcucci, M., Passerini, P., Principi G., and Treves, B., 1986, Apennines and Alps ophiolites and the evolution of the Western Tethys. MemoriedellaSocietàGeologicaItaliana, v. 31, pp. 23-44.

Abbate, E., Bortolotti, V., Passerini, P., Principi, G., and Treves, B., 1994, Oceanisation processes and sedimentary evolution of the Northern Apennine ophiolite suite: a discussion. Memorie della Società Geologica Italiana, v. 48, pp. 117-136.

Artusi, L., 2005, Le antiche porte di Firenze. Alla scoperta delle mura che circondavano la città. Semper Press, Firenze, 80 p.

Attanasio, D., Armiento, G., Brilli, M., Emanuele, M.C., Platanìa, R., and Turi, B., 2000, Multimethod marble provenance determinations: the Carrara marbles as a case study for the combined use of isotopic, 3electron spin resonance and petrographic data. Archaeometry, v. 42, pp. 257-272.

Banchelli, A., Fratini, F., Germani, M., Malesani, P., and Manganelli Del Fà, C., 1997, The sandstone of Florentine historical buildings: individuation of the marker and determination of the supply quarries of the rocks used in some Florentine monuments. Science and Technology for Cultural Heritage, v. 6, pp. 13-22.

Barsottelli, M., Fratini, F, Giorgetti, G, Manganelli Del Fa`, C., and Molli, G., 1998, Microfabric and alteration in Carrara marble: a preliminary study. Science and Technology for Cultural Heritage, v. 7, pp. 115-126.

Barsottelli, M., Cellai, G.F., Fratini, F., and Manganelli Del Fà, C., 2001, The hygrometric behaviour of some artificial stone material. Materials and Structures, v. 34, pp. 211-216.

Bortolotti,V., 1962, Sulla stratigrafia del passaggio Pietraforte-Alberese nell'Appennino Settentrionale. Memorie della Società Geologica Italiana, v. 3, pp. 415-419.

Bortolotti, V., 1963, Contributo alla conoscenza della stratigrafia della serie Pietraforte-Alberese. Bollettino della Società Geologica Italiana, v. 81, pp. 225-304.

Bortolotti, V., 1963, Due nuovi esemplari di Ammoniti nella Pietraforte di Riscaggio (Firenze). Bollettino della Società Geologica Italiana, v. 81, pp. 307-312.

Bortolotti, V., 1967, Le paleocorrenti della Pietraforte. Bollettino della Società Geologica Italiana, v. 86, pp. 687-701.

Bortolotti, V., and Malesani, P., 1967, Correlazioni fra i flysch cretacei delle Prealpi Lombarde e quelli della coltre alloctona dell'Appennino settentrionale. Bollettino della Società Geologica Italiana, v. 86, pp. 265-268.

Bortolotti, V., Fazzuoli, M., Pandeli, E., Principi, G., Babbini, A., and Corti, S., 2001, Geology of the central and eastern Elba Island, Italy. Ofioliti, v. 26, pp. 97-105.

Brocchi, G.B., 1814, Conchiologia fossile subappennina con osservazioni geologiche sugli Appennini e sul suolo adiacente. V. 1-2. StamperiaReale Press, Milano, 712 p.

Cantisani, E., Pecchioni, E., Fratini, F., Garzonio, C.A., Malesani, P., and Molli, G., 2009, Thermal stress in the Apuan marbles: Relationship between microstructure and petrophysical characteristics. International Journal of Rock Mechanics \& Mining Sciences, v. 46, pp. 128-137.

Cantisani, E., Garzonio, C.A., Ricci, M., and Vettori, S., 2013, Relationships between the petrographical, physical and mechanical properties of some Italian sandstones. International Journal of Rock Mechanics \& MiningSciences, v. 60, pp. 321-332.

Carmignani, L., Lazzarotto, L., and Coordinators, 2004, Carta Geologica della Toscana 1:250.000, Direzione delle politiche territoriali e ambientali, Servizio Geologico Italiano, Regione Toscana Press, Firenze.

Cipriani, C., 1958a, Ricerche sui minerali costituenti le arenarie: I) Sulla composizione mineralogica della frazione argillosa di alcune arenarie Macigno. Atti della Società Toscana di Scienze Naturali, v. 65, pp. 86106.

Cipriani, C., 1958b, Ricerche sui minerali costituenti le arenarie: II) Sulla composizione mineralogica della frazione sabbiosa di alcune arenarie Macigno. Atti della Società Toscana di Scienze Naturali, v. 65, pp. 165-220.

Cipriani, C., and Malesani, P., 1966, Ricerche sulle arenarie: XIII) la Pietraforte. Bollettino della Società Geologica Italiana, v. 85, pp. 299-332.

Cipriani, C., and Malesani, P., 1972, Composizione mineralogica della frazione pelitica delle formazioni Macigno e Marnoso Arenacea (Appennino Settentrionale). Memorie Istituto Geologia e Mineralogia Università di Parma, v. 29, pp. 1-24.

Cipriani, N., Magaldi, D., and Malesani, P., 1976, Studio mineralogicopetrografico delle Arenarie di Sarnico (Prealpi Bergamasche) e correlazioni 
con la Pietraforte (Toscana). L'Ateneo Parmense, Acta Naturalia, v. 12, pp. 285-309.

Conforti, C., Dulio, R., Marandola, M., Musumeci, N., and Ricco, P., 2016, La Stazione di Firenze di Giovanni Michelucci e del Gruppo Toscano 1932-1935. Mondadori Electa Press, Milano, 144 p.

Dickinson, W. R., 1970, Interpreting detrital modes of greywacke and arkose. Journal of SedimentaryPetrology, v. 40, pp. 695-707.

Falorni, P., 2001, Pietraforte. In: Delfrati, L., Falorni, P., Groppelli, G., Pampaloni, R., and Petti, F.M. (Eds.), Carta Geologica D'Italia, 1:50.000, Catalogo delle Formazioni, Quaderni del Servizio Geologico ISPRA, Serie III, Fascicolo I, Unità Validate, Istituto Poligrafico e Zecca dello Stato Press, Roma, pp. 181-187.

Folk, R.L.,1974, The Petrology of Sedimentary Rock. Hemphill Publishing Company, Austin, Texas, $182 \mathrm{p}$.

Fontana, D. and Mantovani Uguzzoni, M.P., 1987, La frazione terrigena carbonatica nelle arenarie della Pietraforte (Cretaceo Superiore, Toscana meridionale). Bollettino della Società Geologica Italiana, v. 106, pp. 173-181.

Fontana, D., 1991, Detrital carbonate grainsasprovenanceindicators in the UpperCretaceous Pietraforte Formation (northerApennine). Sedimentology, v. 38, pp. 1085-1095.

Fratini, F., and Rescic, S., 2013, The stone materials of the historical architecture of Tuscany, Italy. Geological Society London, Special Publications, v. 391, pp. 71-92.

Fratini, F., Pecchioni, E., Cantisani, E., Rescic,S., and Vettori, S., 2015, Pietra Serena: the stone of the Renaissance. Geological Society London, Special Publications, v. 407, pp. 173-186.

Lotti, B., 1910, Geologia della Toscana. Memoriedescrittive dellaCarta Geologica d'Italia, v. 13, 484 p.

Losacco, U., 1958, Osservazioni geologiche sulle arenarie della Toscana meridionale. Bollettino della SocietàGeologica Italiana, v. 77, pp. 43-75.

Malesani, P., and Vannucci, S., 1974, Pietra Serena e Pietraforte. In: Ricerche sulla degradazione delle pietre, Accademia Toscana di Scienze e Lettere La Colombaria, Leo Olschki Press, Firenze, pp. 3-34.

Malesani, P., Pecchioni, E., Cantisani, E., and Fratini, F., 2003, Geolithology and provenance of the materials of some historical buildings and monuments of Florence's centre (Italy). Episodes, v. 26, pp. 250-255.

Marroni, M., Pandeli, E., Pandolfi, L., and Catanzariti, R., 2015, Updated

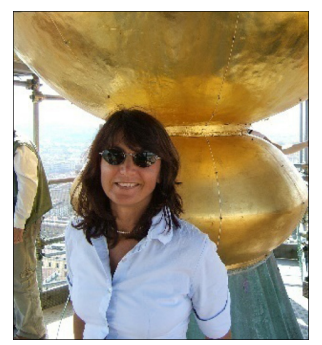

Elena Pecchioni is a graduate technician and conservation scientist at Earth Science Department - University of Florence, since 1990.Graduated in Geological Sciences at the University of Florence in 1985 and specialized in Science for the Conservation of Cultural Heritage in 1992. She has worked as scholarship holder until 1990 in the CNR - CSCOA of Florence. Her researches concern the archaeometry of natural and artificial stone materials, utilised in monumental architecture and the study of the decay phenomenology, finalized to its conservation. She is member of AiAr, Gabec, SIMP, GNP and in the Editorial Board of the Journal MAA. She is co-author of more than 140 scientific papers and two books. picture of the Ligurian and Sub-Ligurian units in the Mt. Amiata area (Tuscany, Italy): elements for their correlation in the framework of the Northern Apennines. Italian Journal of Geosciences, v. 134, pp. 200-218.

Nirta, G., Pandeli, E., Principi, G., Bertini, G., and Cipriani, N., 2005, The Ligurian Units of Southern Tuscan. Bollettino della SocietàGeologica Italiana, v. 3, pp. 29-54.

Pampaloni, G., 1974, Palazzo Strozzi. Istituto Nazionale di assicurazioni Press, Roma, 145 p.

Pandeli, E., Bertini, G., Castellucci, P., Morelli, M., and Monechi S., 2005, The sub-Ligurian and Ligurian units of the Mt. Amiata geothermal Region (south-eastern Tuscany): new stratigraphic and tectonic data and insight into their relationships with the Tuscan Nappe. Bollettino Società Geologica Italiana, v. 3, pp. 55-71.

Pecchioni, E., Cantisani, E., and Fratini, F., 2012, La città di Firenze: un museo di litologia all'aperto-The city of Florence: an open-air lithologymuseum. In: Pratesi, G., (Ed), Il Museo di Storia Naturale dell'Università degli Studi di Firenze, v. IV, Le collezioni mineralogiche e litologiche, Firenze University Press, Firenze, pp. 245-267.

Ricci Lucchi F., 1972. Sedimentologia, vol. I. CLUEB, Bologna, 217 pp.

Ricci Lucchi F., 1976. Sedimentologia, vol. II. Processi e meccanismi. CLUEB Bologna, $210 \mathrm{pp}$.

Rodolico, F., 1964, Le pietre delle città d'Italia. (2nd edition). Le Monnier Press, Firenze, 504 p.

Sacco, F., 1895, L’Appennino settentrionale parte III. La Toscana. Bollettino della Società Geologica Italiana, v. 14, pp. 186-232.

Sartori, R., 2000, Pietre e "Marmi" di Firenze. Alinea Press, Firenze, 86 p.

Sestini, G., Bruni, P. and Sagri, M., 1986, The flysch basins of the Northern Apennines: a review of facies and of Cretaceous-Neogene evolution. Memorie della Società Geologica Italiana, v. 31, pp. 87-106.

Sznura, F., 1975, L'espansione urbana di Firenze nel Dugento. La Nuova Italia Press, Firenze, 190 p.

Vai, G.B., and Martini, P., 2001, Anatomy of an orogen: the Appennines and adjacent Mediterranean basins. Kluver Academic Press, Dordrecht/ Boston/London, $632 \mathrm{p}$.

Valloni, R., and Zuffa, G.G., 1984, Provenance changes for arenaceous formations of the northern Apennines, Italy. Geological Society of America Bullettin, v. 95, pp. 1035-1039.

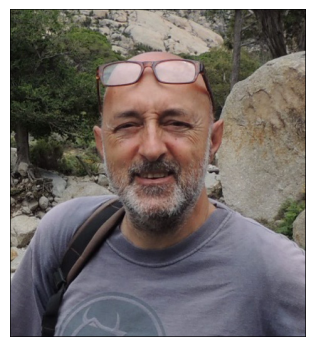

Fabio Fratini is a Researcher at National Research Council of Italy (CNR), Institute of Heritage Science (ISPC), since 1984.Graduated in Geological Sciences at the University of Florence, his research activity concerns the archaeometry of stone materials, bricks, "terracotta", earthen materials and mortars utilised in monumental and vernacular architecture and the study of the decay phenomenologies observed in this heritage, finalized to its conservation. He is member of the scientific Committee of the Congress "Science and Cultural Heritage" which take place in Brixen since 1985 and he participates to the activity of UNI Committee for standardisation concerning Historic Mortars and restoration Mortars. He is co-author of more than 300 scientific papers 


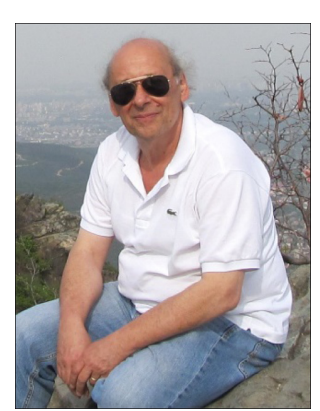

Enrico Pandeli is Graduated in Geological Sciences at the University of Florence in 1979, he began his activity in 1981 at the National Geothermal Unit - ENEL (National Electricity Board) in Pisa. Since 1990, he moved to the Department of Earth Sciences of the University of Florence where he carried out teaching (courses in Geology, Regional Geology and Geothermics) and scientific activities as Associate Professor. Since 2012 he is also Adjunct Professor of Geology and Geothermics at HUST University (Huazhong University of Science and Technology) in Wuhan, Hubei (China) and scientific consultant for geological and geothermal activities in public organizations and in private companies. His research activity in Earth Sciences is documented by more than 150 publications in national and international journals, numerous abstracts and proceedings of national and international congresses, geological maps, more than 50 divulgative contributions (e.g. geological field trip guides) and text-books.

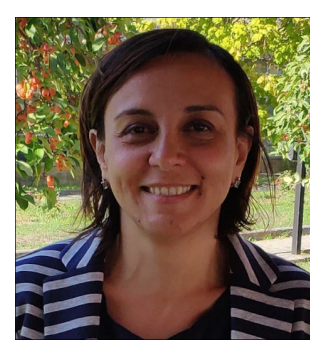

Emma Cantisani is a Researcher at National Research Council of Italy (CNR), Institute of Heritage Science (ISPC). PhD Degree in "Science for the Conservation of Cultural Heritages" at University of Florence (Italy). Main interest: mineralogical, petrographic, chemical and physico-mechanical characterization of natural and artificial lapideous stones for archaeometric and conservative purposes, archaeometric studies on white and colored marbles, set-up of new non-invasive methodologies for the characterization of white marbles. Teacher in master programs and courses, supervisor of degree theses. Author of numerous research articles, books and reports in the field of diagnosis and conservation of cultural heritage.

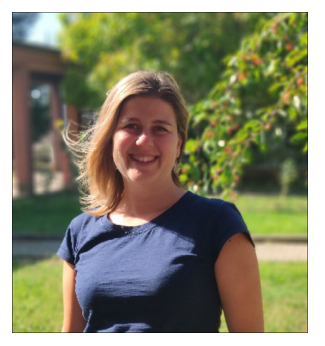

Silvia Vettori is a Researcher at National Research Council of Italy (CNR), Institute of Heritage Science (ISPC), since 2017. PhD Degree in "Earth Sciences" at University of Florence (Italy). The her experiences involve the development and application of methodologies and products for the (mineralogical, petrographic, chemical and physico-mechanical) characterization, enhancement, conservation and monitoring of Cultural Heritage. She took part in several diagnostic campaigns on artefacts of historical and artistic interest (such as bronze and white marble sculptures, pigments, ancient mortars and ceramics). 